\title{
DETEKSI BAKTERI PEMBENTUK AMINA BIOGENIK PADA IKAN SCOMBRIDAE SECARA MULTIPLEX PCR
}

Rizsa Mustika Pertiwi ${ }^{\star 1}$, Mala Nurilmala ${ }^{1}$, Asadatun Abdullah ${ }^{1}$, Nurjanah ${ }^{1}$, Roza Yusfiandayani $^{2}$, M. Fedi A. Sondita ${ }^{2}$

${ }^{1}$ Departemen Teknologi Hasil Perairan, Fakultas Perikanan dan Ilmu Kelautan, IPB University ${ }^{2}$ Departemen Pemanfaatan Sumberdaya Perikanan, Fakultas Perikanan dan Ilmu Kelautan, IPB University Kampus IPB Darmaga, Jalan Agatis, Bogor 16680 Jawa Barat Telepon (0251) 8622909-8622906, Faks. (0251) 8622915

${ }^{\star}$ Korespondensi: rizsa_mustikap@apps.ipb.ac.id Diterima: 22 Juli 2020/ Disetujui: 29 Agustus 2020

Cara sitasi: Pertiwi RM, Nurilmala M, Abdullah A, Nurjanah, Yusfiandayani R, Sondita MFA. 2020. Deteksi bakteri pembentuk amina biogenik pada ikan Scombridae secara multiplex PCR. Jurnal Pengolahan Hasil Perikanan Indonesia. 23(2): 359-371.

\begin{abstract}
Abstrak
Amina biogenik merupakan komponen basa nitrogen yang terbentuk oleh dekarboksilasi asam amino. Amina biogenik yang sering terdeteksi pada produk perikanan di antaranya histamin, tiramin dan kadaverin. Gen pengkode dekarboksilasi asam amino tersebut yaitu histidine decarboxylase (hdc), tyrosine decarboxylase $(t d c)$ serta lysine decarboxylase $(l d c)$. Penelitian ini bertujuan untuk mendapatkan isolat DNA bakteri dengan konsentrasi dan kemurnian yang baik, menyeleksi media pertumbuhan bakteri, menyeleksi media pertumbuhan bakteri yang dapat mengekspresikan gen pembentuk amina biogenik menggunakan teknik multiplex PCR serta mengidentifikasi bakteri pembentuk amina biogenik. Sampel yang digunakan yaitu ikan tuna beku, tongkol beku, cakalang beku, tuna loin, pindang potong dan pindang bumbu kuning serta kontrol positif menggunakan ikan tuna yang disimpan pada suhu ruang selama 3 hari. Penelitian terdiri dari tahap pra-pengayaan bakteri pada media marine broth dan lactose broth, isolasi DNA sampel tanpa dan hasil pra-pengayaan, uji kemurnian dan konsentrasi isolate, amplifikasi gen target $h d c, t d c, l d c$ menggunakan multiplex PCR serta sekuensing dan analisis bakteri pembentuk amina biogenik. Hasil yang diperoleh yaitu kualitas isolat DNA bakteri pada umumnya sudah murni (rasio A260/280: 1.49-2.17) dengan konsentrasi isolat 15,75-461,75 ng/ $\mu \mathrm{L}$. Teknik multiplex PCR berhasil mengekpresikan gen $h d c, t d c$ dan $1 d c$ pada ikan scombridae pada media pra-pengayaan marine broth. Kondisi optimum amplifikasi PCR yaitu annealing pada suhu $50^{\circ} \mathrm{C}$ selama 90 detik. Bakteri pembentuk amina biogenik teridentifikasi yaitu pembentuk histamin M. morganii, E. aerogenes dan A. baumannii, pembentuk cadaverin yaitu Citrobacter sp., Hafnia paralvei, Obesumbacterium proteus, Enterobacter cloacae dan Enterobacter hormaechei, pembentuk tiramin yaitu Enterococcus faecalis.
\end{abstract}

Kata kunci: $h d c, l d c$, scombridae, $t d c$.

\section{Detection of Biogenic Amine Producing Bacteria in Scombridae Fish based on Multiplex PCR assay}

\begin{abstract}
Biogenic amines are nitrogenous base components formed by amino acid decarboxylation. Biogenic amines that are often detected in fishery products are histamine, tyramine and cadaverine. The amino acid decarboxylation coding genes are histidine decarboxylase $(h d c)$, tyrosine decarboxylase $(t d c)$ and lysine decarboxylase $(\mathrm{ldc})$. The purpose of this study was to isolate DNA, select pre-enrichment media that can express biogenic amine forming genes using multiplex PCR, as well as identify biogenic amine forming bacteria. The specimens used were frozen tuna, little tuna, skipjack, and loin tuna. In addition, Indonesian traditional tuna sucha as pindang potong, pindang bumbu kuning were observed. Tuna stored at room temperature for 3 days was used as positive control. The study consisted of the pre-enrichment stage of bacteria on lactose broth and marine broth medias, DNA isolation (sample with and non pre-enrichment), purity test and isolate concentration of target gene of $h d c$, $t d c$, $l d c$ using multiplex PCR. The result obtained were generally in a good quality of bacterial DNA isolates, with concentration ranged between 15.75-157.84 $\mathrm{ng} / \mu \mathrm{L}$. The multiplex PCR was successful in expressing $h d c$, $t d c$ and $l d c$ genes in scombridae fish on marine
\end{abstract}


broth pre-enrichment media. The optimum condition for PCR amplification was annealing at $50^{\circ} \mathrm{C}$ for 90 seconds. Biogenic amine bacteria were identified, namely histamine forming bactria were Morganella morganii, Enterobacter aerogenes and Acinetobacter baumannii, cadaverin forming bacteria were Citrobacter sp., Hafnia paralvei, Obesumbacterium proteus Enterobacteer cloacae and Enterobacter hormachei, tyramine forming bacteria is Enterococcus faecalis.

Keywords: $h d c, l d c$, scombridae, $t d c$.

\section{PENDAHULUAN}

Amina biogenik merupakan komponen basa nitrogen yang terbentuk oleh pemecahan asam amino. Asam amino prekursor terbentuknya biogenik amin yaitu histidina, ornitina, putresina, lisina, tirosina dan arginina yang dapat membentuk amina biogenik histamin, putresin, kadaverin, tiramin, spermin dan spermidin. Amina biogenik banyak ditemukan pada produk perikanan di antaranya pada ikan scombridae sering disebut juga dengan scombrotoxin. Pembetukan amina biogenik terjadi karena dekarboksilasi asam amino oleh bakteri. Bakteri-bakteri yang mampu mendekarboksilasi asam amino antara lain: Enterobacter, Clostridium, Hafnia, Klebsiella, Lactobacillus, Photobacterium, Proteus, Pseudomonas dan Vibrio spp. (Mahamudin et al. 2016), Citrobacter spp., Serratia spp., dan Morganella morganii (Arulkumar et al. 2018).

Teknik penanganan terutama suhu dan waktu penyimpanan sangat memengaruhi kualitas ikan serta mengakibatkan pembentukan amina biogenik pada produk perikanan. Nurjanah et al. (2020) melaporkan bahwa asam amino tertinggi yang terdapat pada ikan tuna sirip kuning yaitu leusina dan lisina, asam amino tersebut mengalami perubahan selama penyimpanan suhu dingin. Fatuni et al. (2014) melaporkan bahwa histamin pada pindang ikan tongkol selama penyimpanan 32 jam meningkat dari $0,26 \mathrm{mg} / 100 \mathrm{~g}$ menjadi $7,54 \mathrm{mg} / 100 \mathrm{~g}$ dan terdeteksi 6 jenis bakteri pembentuk histamin tersebut. Norita et al. (2019) melaporkan bahwa penyimpanan ikan tongkol abu-abu pada suhu ruang selama 2 hari membentuk histamin melebihi standar FAO (2012) yaitu $15 \mathrm{mg} / \mathrm{kg}$, sedangkan penyimpanan pada suhu dingin $\left(0 \pm 3^{\circ} \mathrm{C}\right)$ dan suhu beku $\left(-10 \pm 4^{\circ} \mathrm{C}\right)$ selama 18 hari berada dibawah standar FAO. Nurilmala et al. (2019) melaporkan bahwa ikan tongkol pada penyimpanan dingin $\left(8 \pm 3^{\circ} \mathrm{C}\right)$ selama 7 hari, menurunkan tingkat penerimaan organoleptik, nilai total volatile base (TVB) dan meningkatkan total plate count (TPC) dengan kadar histamin yang terukur 1,96 ppm.

Polymerase chain reaction (PCR) salah satu metode untuk mendeteksi amina biogenik secara cepat dan akurat walaupun dalam konsentrasi yang rendah, dapat dilakukan dengan target spesifik gen penyandi atau bakteri pembentuknya. Deteksi amina biogenik melalui gen penyandi yaitu deteksi enzim yang dihasilkan oleh bakteri pendekarboksilasi asam amino. Gen yang yang dapat menyandikan adanya amina biogenik di antaranya histidine decarboxylase $(h d c)$ sebagai penyandi pembentukan histamin, tyrosine decerboxylase $(t d c)$ sebagai penyandi pembentukan tiramin, lysine decarboxylase (ldc) sebagai penyandi kadaverin dan ornithine decarboxylase (odc) sebagai penyandi putresin. Nurilmala et al. (2019) melaporkan bahwa gen $h d c$ terekspresi pada ikan tongkol abu-abu dan bakteri yang teridentifikasi yaitu Enterobacter sp.. Deteksi gen pembentuk amina biogenik pada ikan scombridae telah dilakukan secara singleplex PCR di antaranya Saputri (2019) pada gen $h d c$, Abdullah et al. (2020) berhasil mengaplikasikan teknik end-point PCR untuk mendeteksi gen $t d c$, serta Nadya (2019) pada gen $l d c$ dan $o d c$, namun $o d c$ tidak terdeteksi pada ikan scombridae tersebut. Deteksi multiplex PCR diharapkan dapat dilakukan untuk mendeteksi ketiga gen target.

Multiplex PCR dapat mendeteksi multi target dalam 1 reaksi yang dapat menghemat waktu kerja di laboratorium. De las Rivas et al. (2005) melaporkan gen $h d c, t d c$ dan odc terekspesi menggunakan multiplex PCR dengan bakteri yang terdeteksi yaitu $K$. planticola, Proteus vulgaris, P. phosphoreum M. morganii serta Staphylococcus sp. Escherichia coli dan Serratia liquefaciens. Deteksi gen $h d c$, $t d c$ dan $l d c$ pada ikan scombridae dari perairan 
Indonesia perlu dilakukan secara multiplex untuk deteksi cepat secara molekuler. Tujuan penelitian ini yaitu mendapatkan isolat DNA bakteri dengan konsentrasi dan kemurnian baik, menyeleksi media pertumbuhan bakteri yang dapat mengekspresikan gen pembentuk amina biogenik menggunakan teknik multiplex PCR serta identifikasi bakteri pembentuk amina biogenik.

\section{BAHAN DAN METODE Bahan dan Alat}

Bahan utama yang digunakan yaitu ikan tuna beku, tongkol beku, cakalang beku yang ditangkap dari Perairan Binuangeun Banten pada bulan Juli 2018, tuna loin diperoleh dari pasar swalayan di Bogor, pindang bumbu kuning dan pindang potong diperoleh dari warung sayur yang berada di sekitar kampus IPB Dramaga. Kontrol positif menggunakan ikan tuna yang disimpan pada suhu ruang selama 3 hari serta kontrol negatif $\mathrm{ddH}_{2} \mathrm{O}$, media lactose broth dan marine broth. Bahan kimia untuk analisis yaitu media marine broth (MB), lactose broth (LB) (DifcoTM, Becton, Dickinson and Company AS), kit isolasi DNA yang terdiri dari proteinase $\mathrm{K}$, buffer GA, GB, GD, PW dan TE (TIANamp Genomic DNA Kit, TianGen Biotech, Beijing), dd $\mathrm{d}_{2} \mathrm{O}$, TBE Buffer (AccuGENETM 10X TBE Buffer, Lonza, Rockland, ME AS), marker (VC 100 bp plus DNA ladder (VIVANTIS, Selangor Darul Ehsan, Malaysia), agaros (SeaKem ${ }^{\circ}$ LE Agarose, Lonza, Rockland, ME AS), cybergreen, kapa Taq PCR (Qiagen).

Alat yang digunakan yaitu coolbox, freezer (GEA), mikro sentrifuge (Corning, AS), vortex (Biosan, Latvia), spindown (Corning, New York, AS), UV Transilluminator (Uvitec, Cambridge, Inggris), microwave (Sharp, Osaka, Jepang), spektrofotomer UV-Vis, PCR konvensional (Anlaytic Jena, AS), elektroforesis (HU6, SCIE-PLAS, Cambrige, Inggris).

\section{Metode Penelitian}

Penelitian yang dilakukan terdiri dari preparasi sampel, pra-pengayaan bakteri, isolasi DNA, uji kualitas dan kuantitas isolat kemudian amplifikasi menggunakan multiplex PCR. Sampel beku dilelehkan pada suhu ruang kemudian dipisahkan bagian daging dari tulang, kulit dan jeroannya, daging ikan yang diperoleh dilumatkan menggunakan blender. Daging lumat yang digunakan masing-masing dari 1 ekor ikan beku utuh dan pindang bumbu kuning sedangkan pindang potong menggunakan 3 potong. Kontrol positif menggunakan ikan tuna yang disimpan pada suhu ruang selama 3 hari. Lumatan daging ikan disiapkan untuk isolasi (tanpa pra-pengayaan) ataupun prapengayaan pada media pertumbuhan bakteri yaitu lactose broth dan marine broth. Daging halus sebanyak 2 gram dalam $50 \mathrm{~mL}$ media lactose broth ataupun marine broth, diinkubasi selama 16 jam pada suhu $37^{\circ} \mathrm{C}$ kemudian disentrifugasi pada $13.000 \mathrm{rpm}$ selama 3 menit. Endapan yang dihasilkan merupakan biomassa yang akan digunakan selanjutnya dalam tahap isolasi DNA.

\section{Isolasi DNA}

Isolasi DNA dilakukan 1 kali ulangan pada daging ikan tanpa pra-pengayaan dilakukan sebanyak $25 \mathrm{mg}$, sedangkan pada biomassa bakteri hasil pra-pengayaan sebanyak endapan yang terdapat pada tube 2 $\mathrm{mL}$ hasil sentrifugasi. Isolasi DNA dilakukan sesuai dengan prosedur TIANamp Genomik DNA Kit. Sampel dicampur dengan $200 \mu \mathrm{L}$ buffer GA dalam tube $2 \mathrm{~mL}$, ditambahkan proteinase $\mathrm{K} 20 \mu \mathrm{L}$ divortex, ditambahkan buffer GB $220 \mu \mathrm{L}$ vortex 15 detik. Campuran sampel diinkubasi pada $70^{\circ} \mathrm{C}$ selama 10 menit, spindown untuk memisahkan kotoran atau sisa sampel sedangkan filtrat dipindahkan dalam tube baru. Filtrat ditambahkan etanol sebanyak $220 \mu \mathrm{L}$, vortex kemudian dipindahkan ke dalam spin column dan sentrifugasi pada $13.400 g( \pm 12.000 \mathrm{rpm})$ selama 30 detik, cairan yang terpisah dari kolom dibuang. Buffer GD sebanyak $500 \mu \mathrm{L}$ ditambahkan ke dalam spin column kemudian sentrifugasi kembali pada $13.400 \mathrm{~g}( \pm 12.000$ rpm) selama 30 detik. Penambahan buffer PW ke dalam spin column sebanyak $600 \mu \mathrm{L}$, sentrifugasi kembali pada $13.400 \mathrm{~g}( \pm 12.000$ rpm) selama 30 detik, proses penambahan buffer PW dilakukan sebanyak 2 kali. Spin column disentrifugasi kembali pada 13.400 $g( \pm 12.000 \mathrm{rpm})$ selama 2 menit, kemudian 
tampungan diganti dengan tube baru. Buffer TE ditambahkan sebanyak $200 \mu \mathrm{L}$, inkubasi selama 5 menit, kemudian sentrifugasi 13.400 $g( \pm 12.000 \mathrm{rpm})$ selama 2 menit. Filtrat yang terkumpul pada tube merupakan isolat DNA.

\section{Elektroforesis, pengukuran konsentrasi dan kemurnian isolat}

Elektroforesis ditujukan untuk menentukan keberhasilan isolasi DNA secara visual dilakukan mengacu pada Nurilmala et al. (2020). Elektroforesis yang digunakan yaitu elektroforesis horizontal dengan gel agaros $1,2 \%(0,6 \mathrm{~g}$ agaros dalam 50 $\mathrm{mL}$ buffer TBE), pembuatan agaros dididihkan pada suhu $130^{\circ} \mathrm{C}$ selama 20 menit kemudian didiamkan pada suhu ruang hingga suhu $50-60^{\circ} \mathrm{C}$ baru dituangkan dalam cetakan. Sisir dipasang saat penuangan agar sebagai sumur yang akan digunakan untuk sampel. Gel ditunggu hingga mengeras kurang lebih 20 menit, kemudian direndam dengan buffer TBE.

Isolat DNA sebanyak $3 \mu \mathrm{L}$ dicampurkan dengan $3 \mu \mathrm{L}$ cybergreen dan $3 \mu \mathrm{L}$ loading dye, kemudian dimasukkan ke dalam sumur. Elektroforesis dijalankan pada 100 Volt dan $60 \mathrm{~mA}$ selama 30 menit. Hasil elektroforesis diamati pada sinar UV, keberhasilan isolasi akan terbentuk pita yang berpendar. Marker ditambahkan pada saat elektroforesis dengan penambahan cybergreen dan loading dye masing-masing $3 \mu \mathrm{L}$, keberadaan marker berfungsi sebagai indikator.

Pengukuran kuantitas isolat DNA yaitu kemurnian dan kosentrasinya menggunakan spektrofotometer UV-Vis nanodrop pada panjang gelombang $260 \mathrm{~nm}$ dan $280 \mathrm{~nm}$ (Fatchiyah et al. 2011). Kemurnian diukur berdasarkan perbandingan nilai absorbansi $260 \mathrm{~nm}$ terhadap $280 \mathrm{~nm}$. Konsentrasi DNA diukur menggunakan rumus perkalian tanara nilai absorbansi pada panjang gelombang $260 \mathrm{~nm}$ terhadap 50 dan faktor pengencer, 50 merupakan nilai koreksi larutan dengan nilai absorbansi 1.0 sebanding dengan $50 \mu \mathrm{g}$ untai ganda DNA per mil, sedangkan faktor pengencer pada penelitian ini 1 karena tidak ada pengenceran.

\section{Amplifikasi DNA pada Polymerase Chain Reaction (PCR)}

Amplifikasi DNA bakteri pembentuk amina biogenik menggunakan PCR konvensional metode multiplex dengan spesifik primer gen $h d c, t d c$ dan $l d c$ (Table 1). Bahan dalam reaksi PCR terdiri dari $\mathrm{dd}_{2} \mathrm{O}$ $(4,5 \mu \mathrm{L})$, DNA multiplex PCR kit $(12,5 \mu \mathrm{L})$, primer forward hdc $(1 \mu \mathrm{L})$, primer reverse $h d c(1 \mu \mathrm{L})$, primer forward tdc $(1 \mu \mathrm{L})$, primer reverse tdc $(1 \mu \mathrm{L})$, primer forward ldc $(1 \mu \mathrm{L})$, primer reverse $l d c(1 \mu \mathrm{L})$ dan isolat DNA (2 $\mu \mathrm{L})$.

Proses PCR dijalankan sesuai protokol Quick-Star Protocol (Qiagen Multiplex PCR kit) dengan modifikasi. Suhu annealing optimum primer $h d c$ yaitu $54^{\circ} \mathrm{C}, t d c 53^{\circ} \mathrm{C}$ dan ldc $45^{\circ} \mathrm{C}$, namun setelah melalui percobaan pendahuluan diperoleh suhu $50^{\circ} \mathrm{C}$ yang memapu mengekspresikan ketiga gen target tersebut. Initial heat activation dijalankan pada suhu $95^{\circ} \mathrm{C}$ selama 15 menit, denaturasi pada suhu $94^{\circ} \mathrm{C}$ selama 30 detik, annealing pada suhu $50^{\circ} \mathrm{C}$ selama 90 detik, extention pada suhu $72^{\circ} \mathrm{C}$ selama 60 detik dan final extention pada suhu $72^{\circ} \mathrm{C}$ selama 15 menit. Siklus amplifikasi sebanyak 35 kali dari tahap denaturasi hingga extention. Produk PCR yang

Table 1 Specific primer PCR

\begin{tabular}{|c|c|c|c|c|}
\hline Gene & Primer & Sequence & $\begin{array}{l}\text { Size product } \\
\text { (bp) }\end{array}$ & Source \\
\hline \multirow[t]{2}{*}{$h d c$} & HDC2-F & TGGGGTTATGTSACCAATGG & \multirow[t]{2}{*}{571} & \multirow{2}{*}{$\begin{array}{l}\text { Wongsariya et al } \\
\text { (2015) }\end{array}$} \\
\hline & HDC2-R & GTRTGGCCGTTACGYGARCC & & \\
\hline \multirow[t]{2}{*}{$l d c$} & CAD1-F & TTYGAYWCNGCNTGGGTNCCNTAYAC & \multirow[t]{2}{*}{1,098} & \multirow{2}{*}{$\begin{array}{l}\text { de las Rivas et al } \\
(2006)\end{array}$} \\
\hline & CAD1-R & CCRTGDATRTCNGTYTCRAANCCNGG & & \\
\hline \multirow[t]{2}{*}{$t d c$} & TDC-F & TGGYTNGTNCCNCARACNAARCAYTA & \multirow[t]{2}{*}{825} & \\
\hline & TDC-R & ACRTARTCNACCATRTTRAARTCNGG & & \\
\hline
\end{tabular}


diperoleh kemudian divisualisasikan kembali menggunakan elektroforesis pada konsentrasi agaros $1,2 \%$. Sampel yang dilakukan sekuensing dilakukan juga pemurnian dan elektroforesis pada $0,8 \%$.

\section{Analisis bioinformatika}

Pita DNA kontrol positif tanpa dan dengan pra-pengayaan serta isolat hasil pra-pengayaan terpilih yang mampu mengekspresikan ketiga gen target di sekunesing untuk menerjemahkan urutan DNA menjadi untaian basa nukleotida. Sekuensing menggunakan prinsip (Sanger dan Culson 1975) di PT Genetika Science dan hasil yang diperoleh berupa kromatogram untaian basa nukleotida. Sekuen yang diperoleh kemudian dianalisis bioinformatika menggunakan perangkat lunak MEGA X (Molecular Evaluationary Genetic Analysis) dan Basic Local Alignment Search Tool (BLAST) untuk menentukan spesies bakteri pembentuk amina biogenik.

\section{HASIL DAN PEMBAHASAN \\ Kualitas dan Kuantitas Isolat DNA}

Isolasi merupakan tahap awal dalam identifikasi berbasis DNA Dengan prinsip perusakan dinding sel (lisis), pemisahan DNA dari bahan padat seperti selulosa dan protein, serta pemurnian DNA (Surzycki 2000). DNA tidak kasat mata sehingga perlu divisualisasikan salah satunya dengan elektroforesis. Elektroforesis memisahkan partikel bermuatan pada gel agaros menggunakan medan listrik sehingga terpisah molekul-molekul berdasarkan ukurannya (Agrawal 2008). Visualisasi DNA menggunakan marker sebagai standar atau tolak ukur pita sampel yang kita gunakan. Elektroforegram isolat DNA tanpa prapengayaan dan hasil pra-pengayaan media lactose broth dan marine broth disajikan pada Figure 1.
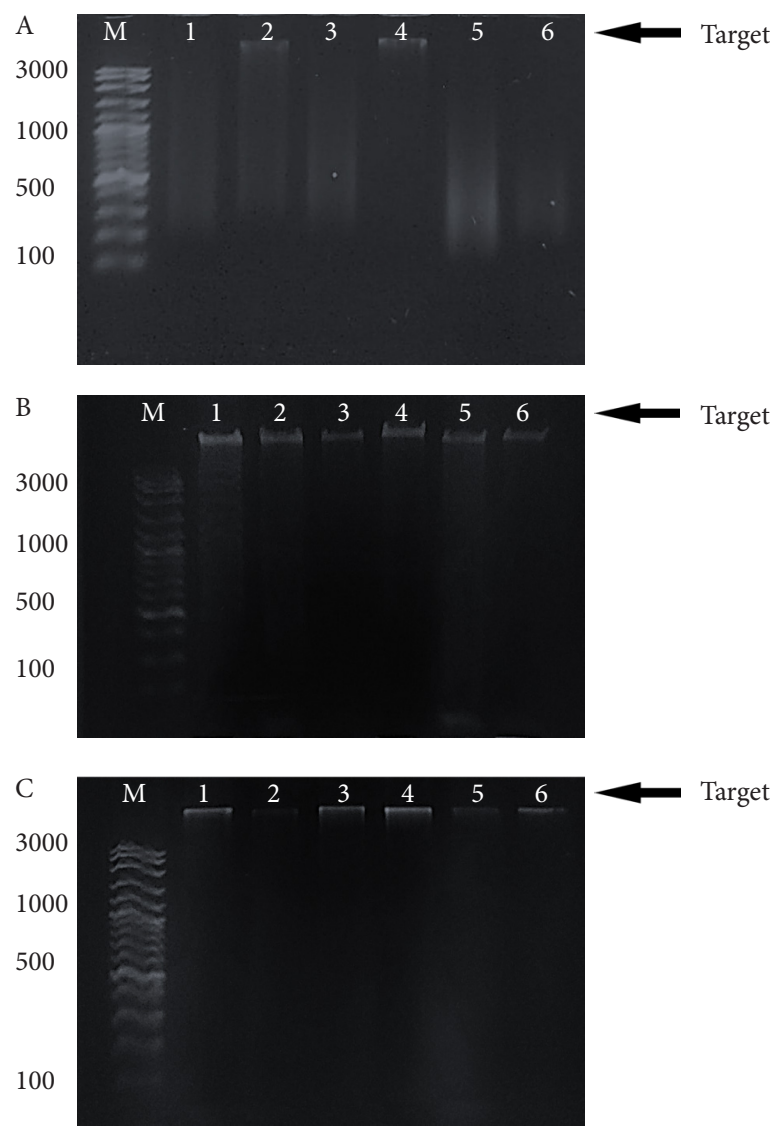

Figure 1 Electroforegram isolate DNA non pre-enrichment (A), with enrichment lactose broth medium (B), marine broth medium (C). M: marker, 1: frozen tuna, 2: little tuna frozen, 3: frozen skipjack, 4: loin tuna, 5: pindang potong, 6: pindang bumbu kuning. 
Table 2 Ratio A260/A280 of bacterial DNA

\begin{tabular}{lrrr}
\hline \multirow{2}{*}{ Sample } & $\begin{array}{c}\text { Non pre- } \\
\text { enrichment }\end{array}$ & \multicolumn{2}{c}{ Medium pre-enrichment } \\
\cline { 3 - 4 } & 2.17 & 1.65 & Lactose broth \\
Frozen tuna & 2.06 & 1.97 & 1.49 \\
Frozen little tuna & 2.09 & 2.02 & 1.53 \\
Frozen skipjack & 2.11 & 1.89 & 1.90 \\
Loin tuna & 2.10 & 1.70 & 1.93 \\
Pindang potong & 1.95 & 1.92 & 1.69 \\
Pindang bumbu kuning & 2.12 & 2.12 & 1.59 \\
Positive control & & & 1.51 \\
\hline
\end{tabular}

DNA bakteri dapat diisolasi pada sampel daging ikan ataupun dengan prapengayaan bakteri terlebih dulu. Isolat DNA menunjukkan pita pada area bobot molekul diatas $3000 \mathrm{bp}$, namun pita pada sampel tanpa pra-pengayaan yaitu tuna beku, cakalang beku dan pindang bumbu kuning terlihat sangat tipis, sedangkan pada pindang potong pita di aera bawah terlihat lebih jelas hal ini dapat terjadi karena adanya pengotor. Pita-pita DNA hasil pra-pengayaan menunjukkan pita yang bersih tanpa ada pengotor atau smear. Hasil pra-pengayaan media lactose broth pitanya cenderung lebih seragam dan tebal. Pita DNA hasil pra-pengayaan media marine broth pada sampel tongkol beku dan pindang potong terlihat lebih tipis dibandingkan dengan pita sampel lainnya. Hasil pra-pengayaan media marine broth secara visual pita terlihat jelas, tanpa pengotor atau smear memiliki konsentrasi dan kemurnian yang baik.

Kemurnian dan konsentrasi isolat diuji menggunakan spektrofotometer pada panjang gelombang 260 dan $280 \mathrm{~nm}$. Sinar pada panjang gelombang $260 \mathrm{~nm}$ dapat diserap oleh basa purin dan pirimidin sebagai penyusun DNA, sedangkan sinar pada panjang gelombang $280 \mathrm{~nm}$ dapat terserap protein dan fenol (Sambrook dan Russell 2001). Kemurnian isolat DNA dapat dilihat pada Table 2.

Rasio A260 dan A280 menunjukkan kemurnian isolat DNA bakteri tanpa dan hasil pra-pengayaan. Kisaran rasio isolat yaitu 1,49-2,12. DNA yang murni pada umumnya berada pada kisaran 1,8-2,0, apabila kurang kurang dari 1,8 menandakan kontaminasi protein, sedangkan apabila lebih dari 2,0 ada kontaminasi RNA (Olson dan Morrow
2012). Terdapat sampel yang memiliki kemurnian dibawah dan di atas nilai pada umumnya diduga disebabkan oleh adanya komponen pengotor. Komponen-komponen yang biasanya dianggap sebagai pengotor pada isolat DNA di antaranya yaitu protein. Kandungan media pra-pengayaan bakteri mengandung protein yaitu pepton yang diduga masih terbawa pada isolat DNA sehingga memengaruhi kemurniannya, namun pada penelitian ini tidak dilakukan pengkajian komponen pengotor lebih lanjut. Abdullah et al. (2020) melaporkan rasio kemurnian isolat DNA bakteri pada sampel ikan tuna, tongkol dan cakalang yaitu 2,04-2,11 dan berhasil amplifikasi pada proses PCR, oleh karena itu pada penelitian ini dilakukan amplifikasi dengan PCR pada seluruh sampel.

Konsentrasi isolat DNA tanpa dan hasil pra-pengayaan bakteri disajikan pada Table 3. Konsentrasi DNA isolat bakteri tanpa prapengayaan berkisar $15,75-157,85 \mathrm{ng} / \mu \mathrm{L}$, hasil pra-pengayaan lactose broth yaitu 74,40-326,05 $\mathrm{ng} / \mu \mathrm{L}$, hasil pengayaan marine broth 39,35 $461,75 \mathrm{ng} / \mu \mathrm{L}$. Konsentrasi DNA tanpa prapengayaan lebih rendah dibandingkan dengan isolat yang lainnya, hal tersebut seiring dengan terbentuknya pita tipis pada hasil visualisasi. Konsentrasi bakteri sampel dan hasil preenrichment pada penelitian ini tidak di amati, sehingga diduga menjadi salah satu faktor yang menyebabkan konsentrasi isolat tidak sama. Konsentrasi DNA tersebut merupakan DNA seluruh bakteri yang tumbuh dan dapat terekstrak, bahkan sangat memungkinkan kalau didalamnya terdapat bakteri bukan pembentuk amina biogenik. Oleh sebab itu pada penelitian selanjutnya disarankan 
Table 3 Concentration of bacterial DNA

\begin{tabular}{lrrr}
\hline \multirow{2}{*}{ Sample } & $\begin{array}{c}\text { Non pre- } \\
\text { enrichment }\end{array}$ & \multicolumn{2}{c}{ Medium pre-enrichment } \\
\cline { 3 - 4 } & & $\begin{array}{c}\text { Lactose broth } \\
(\mathrm{ng} / \mu \mathrm{L})\end{array}$ & $\begin{array}{c}\text { Marine broth } \\
(\mathrm{ng} / \mu \mathrm{L})\end{array}$ \\
\hline Frozen tuna & 46.30 & 76.55 & 90.85 \\
Frozen little tuna & 47.90 & 94.85 & 39.35 \\
Frozen skipjack & 15.75 & 101.00 & 81.40 \\
Loin tuna & 157.85 & 83.70 & 57.75 \\
Pindang potong & 75.90 & 74.40 & 89.35 \\
Pindang bumbu kuning & 19.45 & 135.70 & 65.00 \\
Positive control & 52.05 & 326.05 & 461.75 \\
\hline
\end{tabular}

gunakan media selektif yang mengandung asam amino prekursor dari amina biogenik yang menjadi target, sehingga yang diisolasi spesifik target bakteri pembentuk amina biogenik.

Nurilmala et al. (2019) melaporkan bahwa ikan tongkol abu-abu hasil kultivasi lactose broth dapat mendeteksi gen $h d c$ namun proses belum efektif, sedangkan Abdullah et al. (2020) melaporkan bahwa metode kultivasi lactose broth berhasil mengekspresikan gen target $t d c$. Media marine broth dipilih karena diharapkan dapat selektif menumbuhkan bakteri yang berasal dari ikan tersebut, bukan dari lingkungan. Bjornsdottir-Butler et al. (2011) berhasil menyeleksi bakteri gram negatif penghasil histamin pada media seleksi marine broth.

Buňková et al. (2011) melaporkan bahwa saat dekarboksilasi asam amino berfungsi sebagai sumber energi bagi bakteri, penambahan berbagai konsentrasi laktosa sebagai sumber energi dapat menurunkan jumlah bakteri namun meningkatkan konsentrasi tiramin, faktor lain yang memengaruhi pembentukan tiramin paling cepat yaitu konsentrasi $\mathrm{NaCl}$ yang semakin meningkat. Pereira et al. (2009) menjelaskan bahwa $\mathrm{Na}^{+}$terlibat dalam pengaturan $\mathrm{pH}$ intraseluler yang berperan penting dalam jalur dekarboksilasi tirosin.

Pengayaan bakteri penghasil amina biogenik pada deteksi berbasis PCR lebih banyak digunakan. Media selektif yang dapat digunakan di antaranya histidine decarboxylase broth yang terdiri dari pepton, hampshire, $\mathrm{NaCl}$, L-histidine $\mathrm{HCl}$ dan air destilasi, $10 \mathrm{~mL}$ media digunakan untuk $0,5 \mathrm{~mL}$ kultur bakteri, diinkubasi selama 72 jam pada $30^{\circ} \mathrm{C}$. Asam sulphosalicylic digunakan untuk memurnikan kultur bakteri dengan teknik pemisahan menggunakan sentrifugasi dan penyaringan menggunakan kertas (Yazgan 2020). Trevisani et al. (2019) mendeteksi bakteri penghasil histamin (histamine-producing bacteria/HPB) pada ikan tuna dengan menumbuhkan bakteri pada media yang terdiri dari TBS $1 \%$, histidin $2 \%$, pyrodoxal $\mathrm{HCl} 0,0005 \%$ dan inkubasi selama 3 hari pada suhu $20^{\circ} \mathrm{C}$. Inokulum ditumbuhkan pada media TSA, media air laut lengkap (pepton, gliserol, agar dan air laut), TCBS dan iron agar. Buňková et al. (2011) mendeteksi bakteri pembentuk tirosin dengan pengayaan pada media M17 broth dengan tambahan tirosin $2 \%, 5 \mathrm{~mL}$ media untuk menumbuhkan inokulum bakteri $25 \mu \mathrm{L}$. Kultivasi bakteri disentrifugasi dan filtrasi untuk mendapatkan kultur murni kemudian dikonfirmasi menggunakan kromatografi ion exchange. Bakteri yang digunakan yaitu Lactococcus lactis subsp. lactis dan L. lactis subsp. cremoris.

\section{Gen Pengkode Amina Biogenik}

Gen pengkode amina biogenik yang diamati di antaranya histidine decarboxylase $(h d c)$ sebagai indikator terbentuknya histamin, tyrosine decarboxylase $(t d c)$ sebagai indikator terbentuknya tiramin, serta lysine decarboxylase (ldc) sebagai indikator pembentukan cadaverine. Pengamatan menggunakan multiplex PCR konvensional, metode ini diharapkan dapat mengekspresikan ketiga gen sekaligus. Elektroforegram deteksi 


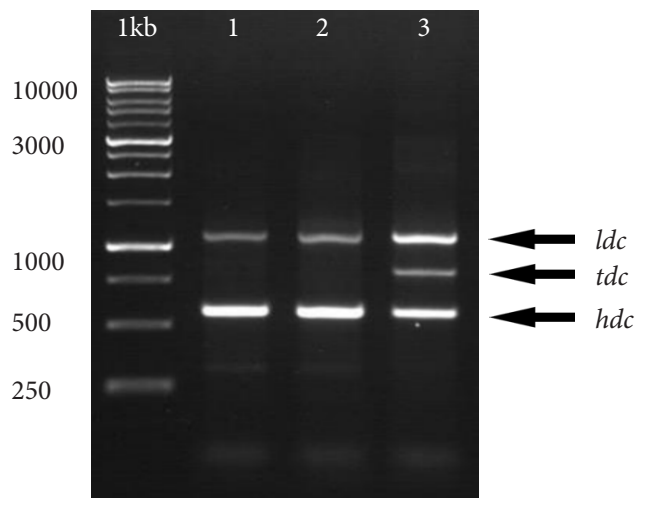

Figure 2 Electrophoregram control of biogenic amine coding gene non pre-enrichment (1) pre-enrichment lactose broth medium (2) and marine broth medium (3).

gen pengkode amina biogenik pada kontrol positif disajikan pada Figure 2.

Figure 2 menunjukkan bahwa gen pengkode amina biogenik yaitu $h d c, t d c$ dan $l d c$ berhasil terekspresi menggunakan multiplex PCR. Target gen $h d c$ yaitu $571 \mathrm{bp}$ (Wongsariya et al. 2015), tdc $825 \mathrm{bp}$ dan $l d c$ 1.098 (de las Rivas et al. 2006). Kontrol positif merupakan ikan tuna yang disimpan selama 3 hari pada suhu ruang untuk mendapatkan isolat bakteri karena belum ada isolat murni bakteri pembentuk amina biogenik. Norita et al. (2019) melaporkan bahwa ikan tongkol yang disimpan pada suhu ruang pada hari ke mengandung histamin $1713,88 \mathrm{mg} / \mathrm{kg}$, sedangkan Saputri (2019) melaporkan ikan tuna yang disimpan pada suhu ruang selama 7 hari mengandung histamin $755.86 \pm 0.09 \mathrm{mg} / /$ kg. Sampel tanpa pra-pengayaan dan prapengayaan pada media lactose broth hanya dapat mengekspresikan gen $h d c$ dan $l d c$, sedangkan hasil pra-pengayaan pada media marine broth dapat mengekpresikan ketiga gen pembentuk amina biogenik. Marine broth selain mengandung sumber energi bakteri juga mengandung mineral yang hanya ditemukan di lingkungan laut, sehingga bakteri yang tumbuh terseleksi bakteri yang berasal dari lingkungan perairan tersebut, oleh karena itu bakteri-bakteri pembentuk amina biogenik dapat tumbuh lebih baik pada media prapengayaan tersebut sehingga pada saat di PCR dapat terekspresikan.

Kondisi yang dipersiapkan dalam tahap multiplex PCR adalah suhu annealing, karena masing-masing primer memiliki suhu optimum yang berbeda. Suhu optimum annealing yang digunakan oleh penelitian sebelumnya yaitu $54^{\circ} \mathrm{C}$ gen $h d c, 53^{\circ} \mathrm{C}$ gen $t d c$ dan $45^{\circ} \mathrm{C}$ gen $l d c$, namun ketika amplifikasi pada masing-masing suhu tersebut, ketiga gen target tidak dapat terekspresi. Hasil dari percobaan pada penelitian ini suhu annealing yang mampu amplifikasi ketiga gen yaitu $50^{\circ} \mathrm{C}$ pada waktu 90 detik sebanyak 35 siklus. Annealing merupakan proses penempelan pada DNA beruntai tunggal dengan primer, biasa dilakukan pada suhu $55-70^{\circ} \mathrm{C}$ selama 20-40 detik atau 3-5 ${ }^{\circ} \mathrm{C}$ lebih rendah dari suhu denaturasi (Verma et al. 2014). Kondisi PCR tersebut digunakan untuk amplifikasi PCR pada sampel ikan tuna beku, tongkol beku, cakalang beku, tuna loin, pindang potong dan pindang bumbu kuning. Elektroforegram hasil PCR disajikan pada Figure 3.

Sampel yang tidak melalui tahap prapengayaan terdeteksi gen $t d c$ pada semua sampel, gen ke $2 h d c$ pada sampel tuna beku dan tuna loin, serta $l d c$ pada sampel tongkol beku. Pita gen $t d c$ dan $l d c$ berada pada bobot target 825 bp dan 1098 bp. Hasil amplifikasi sampel pada pra-pengayaan lactose broth menunjukkan bahwa gen yang terdeteksi yaitu $h d c$ dan $l d c, t d c$ tidak teramplifikasi pada media pra-pengayaan lactose broth sama dengan kotrol yang dianalisis. Amplifikasi sampel yang diperkaya pada media marine broth terdeteksi 3 gen target $(h d c, t d c$ dan $l d c$ ) pada sampel tuna beku, pindang potong dan pindang kuning. Identifikasi gen pada sampel yang ditumbuhkan pada media marine broth terdapat pita-pita yang bukan target yang teramplifikasi karena memiliki kecocokan dengan daerah primer tapi bukan target. 

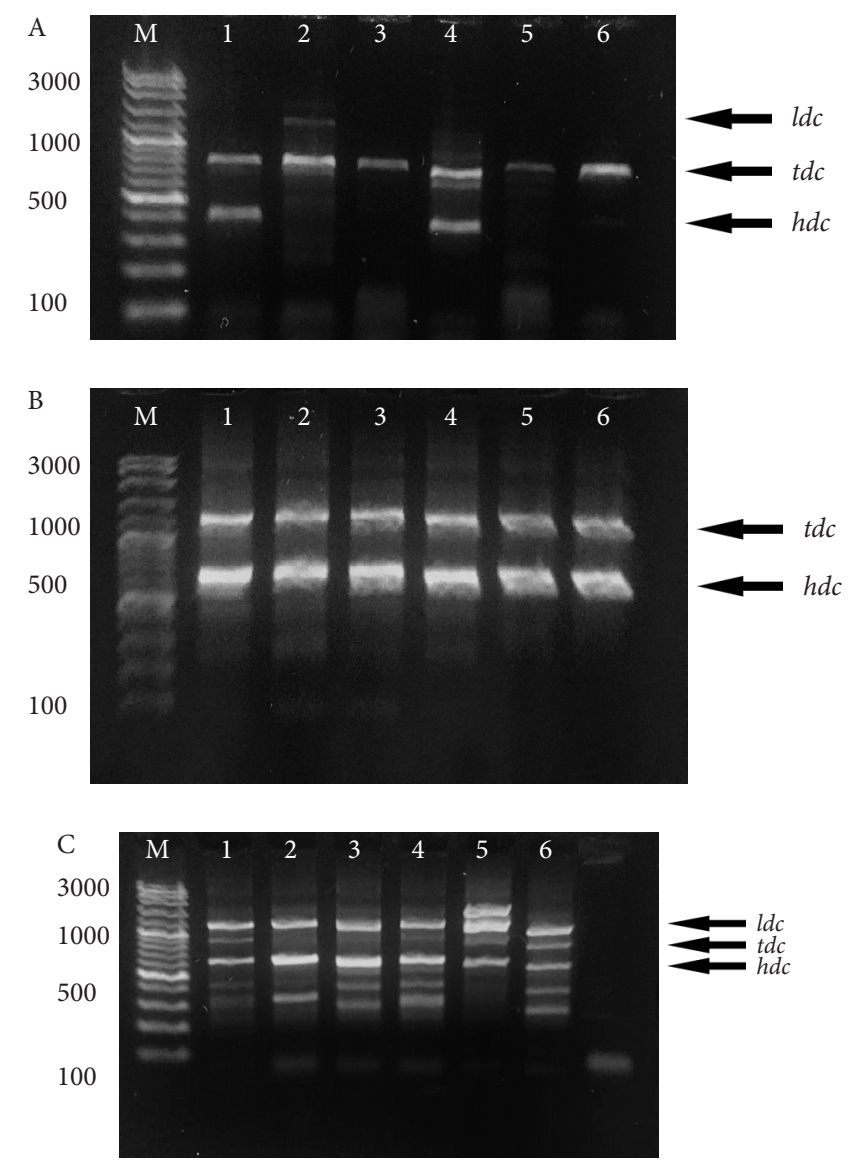

Figure 3 Electrophoregram of biogenic amine coding genes non pre-enrichment (A), with enrichment lactose broth medium (B), marine broth medium (C). M: marker, 1: frozen tuna, 2: frozen little tuna, 3: frozen skipjack, 4: loin tuna, 5: pindang potong, 6: pindang bumbu kuning, 7: negative control.

Yuwono (2006) menyatakan bahwa salah satu penyebab dalam PCR yaitu salah pengenalan DNA cetakan terhadap primernya. Ketiga sampel yang mampu mengekspresikan gen target selanjutnya di sekuensing untuk mengidentifikasi bakteri yang menghasilkan gen tersebut sehingga dapat menyandikan pembentukan amina biogenik.

Gen pengkode amina biogenik berhasil diidentifikasi menggunakan multiplex PCR. Identifikasi bakteri pembentuk amina biogenik dilakukan menggunakan sekuensing, yaitu mengurutkan basa-basa penyusun DNA yang selanjutnya disejajarkan dengan GenBank di National Centre for Biotechnology Information (NCBI) menggunakan Basic Local Alignment Search Tool (BLAST). De las Rivas et al. (2005) melaporkan $h d c$ terekspresi menggunakan multiplex PCR pada 534 bp, bakteri pembentuknya yang terdeteksi yaitu Klebsiella planticola, Proteus vulgaris, Photobacterium phosphoreum dan M. morganii, serta
Staphylococcus sp. pada $367 \mathrm{bp}$, odc terekspresi pada 1.446 bp dengan terdeteksinya bakteri M. morganii, Escherichia coli dan Serratia liquefaciens. Hwang et al. (2010) melaporkan bahwa metode konvensional PCR secara multiplex dapat mendeteksi Staphylococcus piscifermentans, Bacillus subtilis, Bacillus sp. sebagai pembentuk amina biogenik pada produk ikan tuna kayu (katsuobushi).

\section{Analisis Bioinformatika}

Sekuen DNA sampel control tanpa prapengayaan, pra-pengayaan lactose broth dan marine broth, tuna beku, pindang potong dan pindang kuning hasil pra-pengayaan marine broth. Sekunen dianalisis menggunakan BLAST sehingga dapat mengidentifikasi spesies bakteri pembentuk amina biogenik, hasil disajikan pada Table 4. Bakteri yang teridentifikasi pada sampel merupakan bakteri-bakteri pendekarboksilasi amina biogenik. 
Table 4 Species identification with BLAST analysis

\begin{tabular}{|c|c|c|c|c|c|}
\hline Sample & $\begin{array}{c}\text { Pre- } \\
\text { enrichment }\end{array}$ & Gene & Analytical results & $\%$ Identity & $\begin{array}{c}\text { Accession } \\
\text { numbers }\end{array}$ \\
\hline \multirow{7}{*}{$\begin{array}{l}\text { Positive } \\
\text { control }\end{array}$} & Non & $l d c$ & Citrobacter sp. & 83.50 & СР047606.1 \\
\hline & Non & $h d c$ & M. morganii & 99.05 & СР043955.1 \\
\hline & Lactose broth & $l d c$ & Hafnia paralvei & 87.87 & СР014031.2 \\
\hline & Lactose broth & $h d c$ & M. morganii & 85.75 & СР043955.1 \\
\hline & Marine broth & $l d c$ & Obesumbacterium proteus & 77.93 & СР014608.1 \\
\hline & Marine broth & $t d c$ & Enterococcus faecalis & 95.00 & СР046111.1 \\
\hline & Marine broth & $h d c$ & Enterobacter aerogenes & 97.00 & KP728798.1 \\
\hline \multirow[t]{3}{*}{ Frozen tuna } & Marine broth & $l d c$ & Enterobacter cloacae & 91.03 & СР056474.1 \\
\hline & Marine broth & $t d c$ & Enterococcus faecalis & 96.04 & СР030076.1 \\
\hline & Marine broth & $h d c$ & Acinetobacter baumannii & 90.72 & KJ768338.1 \\
\hline \multirow{3}{*}{$\begin{array}{l}\text { Pindang } \\
\text { bumbu kuning }\end{array}$} & Marine broth & $l d c$ & Enterobacter cloacae & 89.46 & СР020528.1 \\
\hline & Marine broth & $t d c$ & Enterococcus faecalis & 88.82 & CP049775.1 \\
\hline & Marine broth & $h d c$ & M. morganii & 93.20 & FJ469561.1 \\
\hline \multirow{3}{*}{$\begin{array}{l}\text { Pindang } \\
\text { potong }\end{array}$} & Marine broth & $l d c$ & Enterobacter hormaechei & 96.04 & СР030076.1 \\
\hline & Marine broth & $t d c$ & Enterococcus faecalis & 95.29 & CP046113.1 \\
\hline & Marine broth & $h d c$ & Acinetobacter baumannii & 94.29 & СР040080.1 \\
\hline
\end{tabular}

Bakteri pembentuk histamin (gen $h d c$ ) yang terdeteksi yaitu M. morganii, E. aerogenes dan $A$. baumannii. Ferrario et al. (2012) melaporkan bahwa bakteri $M$. morganii dan E. hormaechi merupakan bakteri dominan menghasil $h d c$, sedangkan Saputri (2019) melaporkan bahwa bakteri tersebut juga terdeteksi pada ikan tuna, tongkol dan cakalang. Bjornsdottir-buter et al. (2009) melaporkan bahwa bakteri M. morganii, dan Enterobacter sp. merupakan kelompok bakteri penghasil histamin tinggi. A. baumannii juga merupakan bakteri penghasil histamin sesuai dengan hasil deteksi Wongsariya et al. (2015) pada primer $571 \mathrm{bp}$.

Bakteri pembentuk cadaverin (gen ldc) yaitu Citrobacter sp., Hafnia paralvei, Obesumbacterium proteus, Enterobacter cloacae dan Enterobacter hormaechei. Bakteri-bakteri pembentuk cadaverin di antaranya Enterobacter dan Proteus mirablis pada ikan tuna, tongkol dan cakalang (Nadya 2019), Citrobacter freundii pada gurita merah (Klanian et el. 2018), Kluyvera intermedia, Enterobacter aerogenes, Yersinia kristensenii, Serratia grimesii, Serratia ficaria, Yersinia rodhei, Providencia vermicola dan
Obesumbacterium proteus pada sosis sapi (Curiel et al. 2011).

Bakteri pembentuk tiramin (gen $t d c$ ) pada penelitian ini yaitu teridentifikasi Enterococcus faecalis. Abdullah et al. (2020) melaporkan pada identifikasi spesies bakteri pembentuk tiramin di antaranya $C$. divergens dan Enterobacter tabaci, berbeda dengan yang teridentifikasi pada penelitian, mungkin dikarenakan media yang berhasil menumbuhkannya juga berbeda. Bargossi et al. (2015) melaporkan bahwa pengujian bakteri E. faecalis dan E. faecium merupakan bakteri penghasil tiramin, kedua jenis bakteri tersebut menghasilkan tiramin dalam julah yang tinggi sejak fase pertumbuhan eksponensial. Aktivitas tiraminogenik melambat pada fase diam hingga 72 jam inkubasi.

Identifikasi bakteri tersebut dapat dipercaya berdasarkan \%identity bakteri tersebut dengan urutan nukleotida bakteri yang terdapat pada database geneBank dengan kode akses tertentu. Persen identitas yang semakin tinggi menujukkan kemiripan spesies tersebut juga semakin dekat kekerabatan suatu spesies tersebut. 


\section{UCAPAN TERIMAKASIH}

Terima kasih kepada Kementrian Riset, Teknologi dan Pendidikan Tinggi yang telah mendanai penelitian ini pada program Insentif Riset Sistem Inovasi Nasional (INSINAS) a.n Dr. Mala Nurilmala SPi, MSi dengan judul Pengembangan Teknologi Rumpon dan Penjaminan Mutu Terintegrasi pada Perikanan Tuna Tongkol Cakalang Berkelanjutan pada nomor kontrak 12/INS-1/PPK/E4/2019.

\section{KESIMPULAN}

Isolat DNA bakteri memiliki kemurnian 1,49-2,17 dan konsentrasi 19,45-461,75 ng/ $\mu \mathrm{L}$. Media yang mampu mengekspresikan ketiga gen target yaitu marine broth pada kondisi PCR yaitu initial heat activation pada suhu $95^{\circ} \mathrm{C}$ selama 15 menit, denaturasi pada suhu $94^{\circ} \mathrm{C}$ selama 30 detik, annealing pada suhu $50^{\circ} \mathrm{C}$ selama 90 detik, extention pada suhu $72^{\circ} \mathrm{C}$ selama 60 detik dan final extention pada suhu $72^{\circ} \mathrm{C}$ selama 15 menit. Bakteri pembentuk amina biogenik histamin yaitu M. morganii, E. aerogenes dan A. baumannii, pembentuk cadaverin yaitu Citrobacter sp., Hafnia paralvei, Obesumbacterium proteus, Enterobacter cloacae dan Enterobacter hormaechei, pembentuk tiramin yaitu Enterococcus faecalis. Saran pada penelitian ini yaitu penambahan asam amino prekursor pada media pra-pengayaan bakteri serta pemurnian isolat bakteri pembentuk amina biogenik.

\section{DAFTAR PUSTAKA}

Abdullah A, Nurilmala M, Budiarti AS. 2020. Application of end-point PCR technique to detect bacteria encoding tyrosine decarboxylase (TDC) gene in scombridae fish. IOP Conference Series: Earth and Environmental Science. 404:1-8.

Arulkumar A, Paramasivam S, Rameshthangam P, Paramithiotis S. Evaluation of psychrophilic, mesophilic, histamine forming bacteria and biogenic amine content in the muscle of mudspiny lobster, Panulirus polyphagus (HERBST, 1793) during ice storage. Journal of Food Safety. 39: 1-7.
Agrawal S. 2008. Techniques in Molecular Biology. Lucknow (IN): International Book Distributing Co.

Bargossi E, Tabanelli G, Montanari C, Lanciotti R, Gatto V, Gardini F, Torriani S. 2015. Tyrosine decarboxylase activity of enterococci grown in media with different nutritional potential: Tyramine and 2-phenylethylamine accumulation and tyrDC gene expression. Frontiers in Microbiology. 6: 1-10.

Bjornsdottir-Buter K, Bolton GE, McclellanGreen PD, Jaykus LA, Green DP. 2009. Detection of Gram-negative histamineproducing bacteria in fish: a comparative study. Journal of Food Protection. 72(9):1987-1991.

Bjornsdottir-Buter K, Jones JL, Benner R, Bukhardt W. 2011. Development of a real-time PCR assay with an internal amplification control for detection of Gram-negative histamine-producing bacteria in fish. Food microbiology. 28: 356-363.

Buňková L, Bunka F, Pollaková E, Podešvová T, V Dráb. 2011. The effect of lactose, $\mathrm{NaCl}$ and an aero/anaerobic environment on the tyrosine decarboxylase activity of Lactococcus lactis subsp. cremoris and Lactococcus lactis subsp. Lactis. International of Journal of Food Microbiology. 147: 112-119.

Curiel JA, Ruiz-Capillas C, de las Rivas B, Carrascosa AV, Jiménez-Colmenero F, Muñoz R. 2011. Production of biogenic amines by lactic acid bacteria and enterobacteria isolated from fresh pork sausages packaged in different atmospheres and kept under refrigeration. Meat science. 88: 268-373.

de las Rivas B, Marcobal A, Carrascosa AV, Muñoz R. 2006. PCR detection of foodborne bacteria producing the biogenic amines histamine, tyramine, putrescine, and cadaverine. Journal of Food Protection. 69(10): 2509-2514.

De las Rivas B, Marcobal A, Muñoz R. 2005. Improved multiplex-PCR method for the simultaneous detection of food bacteria 
producing biogenic amines. Federation of European Microbiology Societies. 244:367372.

[FAO] Food and Agriculture Organization of the United Nations. 2012. Public Health Risk of Histamine and other Biogenic Amines from Fish and Fishery Products. Rome (IT): Food and Agriculture Organization of the United Nations.

Fatuni YS, Suwandi R, Jacoeb AM. 2014. Identifikasi kadar histamin dan bakteri pembentuk histamin dari pindang badeng tongkol. Jurnal Pengolahan Hasil Perikanan Indonesia. 17(2): 112-118.

Fatchiyah, Arumingtyas ES, Widyarti S, Rahayu S. 2011. Biologi Molekuler Prinsip Dasar Analisis. Jakarta (ID): Penerbit Erlangga.

Ferrario C, Ricci G, Borgo F, Fortina MG. 2012. Species-specific DNA probe and development of a quantitative PCR PCR assay for the detection of Morganella morganii. Letters in Applied Microbiology. 54:292-298.

Hwang CC, Lee YC, Huang YR, Lin CM, Shiau CY, Hwang DF, Tsai YH. 2010. Biogenic amines content, histamineforming bacteria and adulteration of bonito in tuna candy products. Food control. 21: 845-850.

Klanian MG, Díaz MD, Solís MJS. 2018. Molecular characterization of histamineproducing psychrotrophic bacteria isolated from red octopus (Octopus maya) in refrigerated storage. High-Throughput. 7(25): 1-14.

Mahamudin M, Mohtar SH, Alias R. 2016. Effectof different storage conditions towards the formation of histamine producing bacteria incanned tuna (Thunnus spp.). Food control. 6(1): 82-87.

Nadya HF. 2019. Pemanfaatan gen pengkode odc dan ldc untuk deteksi dini pembentukan putresin dan kadaverin pada ikan scombridae. [skripsi]. Bogor (ID): Institut Pertanian Bogor.

Nurilmala M, Abdullah A, Matutina VM, Nurjanah, Yusfiandayani R, Sondita MFA, Hizbullah HH. 2019. Perubahan kimia, mikrobiologis dan karakteristik gen $H D C$ pengkode histidin dekarboksilase pada ikan tongkol abu-abu Thunnus tonggol selama penyimpanan suhu dingin. Jurnal Ilmu Teknologi Kelautan Tropis. 11(2):285-296.

Nurjanah, Abdullah A, Naibaho I, Kartikayani $D$, Nurilmala $M$, Yusfiandayani R, Sondita MFA. 2020. Fish quality and nutritional assessment of yellowfin tuna (Thunnus albacares) during low temperature storage. Earth and Environmental Science. 404: 1-15.

Norita, Nurilmala M, Abdullah A. 2019. Kualitas ikan tongkol abu-abu (Thunnus tonggol) pada kondisi penyimpanan berbeda. Jurnal Pengolahan Hasil Perikanan Indonesia. 22(3): 490-497.

Olson ND, Morrow JB. 2012. DNA extract characterization process for microbial detection methods development and validation. BMC Research Notes. 5(668): 1-14.

Pereira CI, Matos D, San Romão MV, Crespo MTB, 2009. Dual role for the tyrosine decarboxylation pathway in Enterococcus faecium E17: response to an acid challenge and generation of a proton motive force. Applied and Environmental Microbiology. 75: 345-352.

Sambrook J, Russell D. 2001. Molecular Cloning: A Laboratory Manual, $3^{\text {rd }}$ Edition. New York (US): Cold Spring Harbor Laboratory Press.

Saputri NN. 2019. Deteksi bakteri penghasil histamin melalui gen histidin dekarboksilase $(h d c)$ pada ikan tuna, tongkol, dan cakalang. [skripsi]. Bogor (ID): Institut Pertanian Bogor.

Surzycki. 2000. Rapid Isolation of DNA from Staphylococcus aureus. Applied Environmental Microbiology. 46(1): 283285.

Trevisani M, Cecchini M, Fedrizzi G, Corradini A, Mancusi R, Tothi E. 2019. Biosensing the histamine producing potential of bacteria in tuna. Frontiers in. Microbiology. 10: 1-11.

Verma P, Yadav AN, Kazy SK, Saxena AK, 
Suman A. 2014. Evaluating the diversity and phylogeny of plant growth promoting bacteria associated with wheat (Triticum aestivum) growing in central zone of India. International Journal off Current Microbiology Applied Science. 3(5): 432447.

Wongsariya K, Bunyapraphatsara N, Yasawong M, Chomnawang MT. 2015. Development of molecular approach based on PCR assay for detection of histamine producing bacteria. Journal of Food Science Technology. 53(1): 640-648.

Yazgan H. 2020. Biogenic amine production in histidine decarboxylase broth by selected lactic acid bacteria strains. GIDA the Journal of Food. 45(1): 31-38.

Yuwono T. 2006. Teori dan aplikasi polymerase chain reaction. Yogyakarta (ID): Penerbit Andi Yogyakarta. 